\title{
KAJIAN KEBIJAKAN DAN PENGEMBANGAN SEKTOR INFORMAL KOTA PEMATANGSIANTAR
}

\author{
Fauzi \\ Universitas Islam Sumatera Utara \\ fauzi@fe.uisu.ac.id
}

\begin{abstract}
Today, the presence of the urban informal sector is considered one of the emerging economic sectors as a result of the city's high employment growth situation. Those who enter this small-scale business, initially aimed at finding job opportunities and creating income. Identify the distribution of informal sector of Pematangsiantar City, using data from plotting surveys using GPS (Global Positioning System). The distribution of business actors / informal sector activities is identified based on the number of samples taken in conjunction with the dissemination of questionnaires. The number of samples itself is determined using sampling method. The calculation itself is done by means of the number of respondents who choose one of the variables divided by the total number of respondents, namely 50 (fifty) correspondents. Weighting on internal factors of importance is based on the large influence of strategic factors on its strategic position (Freddy Rangkuti, 2001 : 22-24). The number of weights on each internal factor must amount to $=1$ (one) : Total Internal Score $\rightarrow$ Total Strength Weight + Total Weight Weakness $=1$. While the value of weight according to Freddy Rangkuti (2001: 22-24) and Training Spama (2000: 13-14) based on the following provisions: "Scale 1.0 (very important) up to 0.0 (not important)". The average weight value depends on the number of strategic factors (5-10 strategic factors) used After doing the analysis, it can be known that in strengths variables that have the highest sub total is creativity with a value of 0.640. And for weaknesses that have the highest sub total is the source of capital with a value of 0.270. Conclusions based on the results of identification and analysis of the Study of Development and Informal Sector Of Pematangsiantar City, then some conclusions that can be drawn as follows, the Internal Development factor of informal sector of the City of Pematangsiantar consists of several factors of strengths and weaknesses. Variables of the strength of the informal sector of Pematangsiantar City are: motivation, creativity, many kinds / types of business, small capital, and work experience. The variables of the weakness of the informal sector of pematangsiantar city are: level of education, lack of permits, availability of raw materials, facilities and infrastructure, as well as sources of capital.
\end{abstract}

Keywords : Policy, Development, informal sector

ABSTRAK : Dewasa ini, kehadiran sektor informal perkotaan dianggap sebagai salah satu sektor
ekonomi yang muncul sebagai akibat dari situasi pertumbuhan tenaga kerja yang tinggi di kota.
Mereka yang memasuki usaha berskala kecil ini, pada mulanya bertujuan untuk mencari
kesempatan kerja dan menciptakan pendapatan. Identifikasi persebaran sektor informal Kota
Pematangsiantar, menggunakan data hasil survei plotting menggunakan GPS (Global Positioning
System). Adapun persebaran pelaku usaha/kegiatan sektor informal diidentifikasi berdasarkan
jumlah sampel yang diambil bersamaan dengan penyebaran kuisioner. Jumlah sampel sendiri
ditentukan menggunakan metode pengambilan sampling. Perhitungan sendiri dilakukan dengan
cara jumlah responden yang memilih salah satu variabel dibagi total jumlah responden yaitu 50
(lima puluh) koresponden. Pembobotan pada faktor internal tingkat kepentingannya didasarkan
pada besarnya pengaruh faktor strategis terhadap posisi strategisnya (Freddy Rangkuti, 2001 : 22-
$24)$. Jumlah bobot pada masing-masing faktor internal harus berjumlah = 1 (satu) : Skor Total
Internal $\rightarrow$ Total Bobot Kekuatan + Total Bobot Kelemahan = 1. Sedangakan nilai bobot menurut
Freddy Rangkuti (2001 : 22-24) dan Diklat Spama (2000 : 13-14) berdasarkan ketentuan sebagai
berikut : "Skala 1,0 (sangat penting) sampai dengan 0,0 (tidak penting)". Besarnya rata-rata nilai
bobot bergantung pada jumlah faktor-faktor strategisnya (5-10 faktor strategis) yang dipakai
Jurnal Ekonomi Keuangan dan Kebijakan Publik Volume 2, No 2, Desember 2020 
Setelah melakukan analisis, dapat diketahui bahwa pada variabel kekuatan (strengths) yang memiliki sub total tertinggi adalah kreatifitas dengan nilai 0,640. Dan untuk variabel kelemahan (weaknesses) yang memiliki sub total tertinggi adalah sumber modal dengan nilai 0,270. Kesimpulan berdasarkan hasil identifikasi dan analisa Kajian Pengembangan dan Sektor Informal Kota Pematangsiantar, maka beberapa kesimpulan yang dapat ditarik sebagai berikut ini, faktor Internal Pengembangan Sektor Informal Kota Pematangsiantar terdiri dari beberapa faktor kekuatan dan kelemahan. Variabel dari kekuatan sektor informal Kota Pematangsiantar adalah: motivasi, kreatifitas, banyak macam/jenis usaha, modal kecil, serta pengalaman kerja. Adapun variabel kelemahan sektor informal Kota Pematangsiantar adalah: tingkat pendidikan, tidak memiliki izin, ketersediaan bahan baku, sarana dan prasarana, serta sumber modal.

Kata Kunci : Kebijakan, Pengembangan, sektor informal

\section{Pendahuluan}

Dewasa ini, kehadiran sektor informal perkotaan dianggap sebagai salah satu sektor ekonomi yang muncul sebagai akibat dari situasi pertumbuhan tenaga kerja yang tinggi di kota. Mereka yang memasuki usaha berskala kecil ini, pada mulanya bertujuan untuk mencari kesempatan kerja dan menciptakan pendapatan. Kebanyakan dari mereka yang terlibat adalah orang-orang migran dari golongan miskin, berpendidikan rendah dan kurang terampil. Latar belakang mereka bukanlah pengusaha dan juga bukan kapitalis yang mengadakan investasi dengan modal yang besar. Namun harus diakui bahwa banyak di antara mereka telah berhasil mengembangkan usahanya dan secara perlahan-lahan memasuki dunia usaha berskala menengah bahkan berskala besar.

Pengertian sektor informal sendiri lebih sering dikaitkan dengan dikotomi sektor formal-informal. Badan Tenaga Kerja Dunia mengidentifikasi sedikitnya tujuh karakter yang membedakan kedua sektor tersebut: (1) kemudahan untuk masuk (ease of entry), (2) kemudahan untuk mendapatkan bahan baku, (3) sifat kepemilikan, (4) skala kegiatan, (5) penggunaan tenaga kerja dan teknologi, (6) tuntutan keahlian, dan (7) deregulasi dan kompetisi pasar

Sektor informal, secara nyata mampu memberikan pelayanan terhadap kebutuhan masyarakat yang berpenghasilan rendah, sehingga dengan demikian tercipta suatu kondisi pemerataan hasil-hasil pembangunan. Selain itu, Sektor informal mempunyai potensi yang cukup besar untuk memberikan kontribusi terhadap penerimaan Pendapatan Asli Daerah (PAD) di sektor penerimaan retribusi daerah seiring dengan kebutuhan daerah dalam rangka penyelenggaraan otonomi daerah.
Sektor informal masih dianggap sebagai black economy, tidak resmi, mengganggu ketertiban kota, dan bahkan dianggap merusak pranata formal. Misalnya, kebijakan penataan Pedagang Kaki Lima (PKL) selama ini lebih banyak menonjolkan matra "menggusur kemiskinan dan ketimpangan dalam distribusi pendapatan di kota". Adanya fenomena paradoksi antara pemerintah pusat dan pemerintah daerah terhadap sektor informal tersebut, melahirkan kebijakan yang tidak sejalan antara pemerintah pusat dan pemerintah daerah, implikasinya adalah pengelolaan terhadap sektor informal menjadi tidak efektif.

Kota Pematangsiantar yang merupakan salah satu kota berkembang di Provinsi Sumatera Utara, terdapat kegiatan sektor-sektor informal yang menjadi salah satu penggerak perekonomian Kota Pematangsiantar. Untuk itu sudah seharusnya kegiatan pada sektor informal perlu ditangani/ditata secara terpadu dengan melibatkan semua pihak yang berkepentingan (stake holders) dan berorientasi pada pemberdayaan para pelaku sektor informal tersebut. Berdasarkan uraian di atas, maka akan dilakukan kegiatan berupa "Kajian Kebijakan dan Pengembangan Sektor Informal Kota Pematangsiantar".

Dimana nantinya diharapkan Kajian Kebijakan dan Pengembangan Sektor Informal Kota Pematangsiantar ini dapat memberikan arahan dan rekomendasi kepada Pemerintah Daerah Kota Pematangsiantar dalam mengelola dan mengembangkan kegiatan sektor infomal, dengan sasaran pedagang ataupun pelaku usaha yang belum terdaftar atau belum berbadan hukum yang tersebar di Kota Pematangsiantar.

\section{Landasan Teori}

\subsection{Konsep Sektor Informal}

Konsep sektor informal muncul dalam konsep keterlibatan pakar-pakar internasional 
dalam perencanan pembangunan di Dunia Ketiga. Gejala ini muncul setelah kelahiran negara-negara maju setelah berakhirnya Perang Dunia kedua. Pada waktu itu muncullah gagasan-gagasan di tingkat internasional maupun nasional untuk mempercepat laju pertumbuhan ekonomi pada negara-negara dimaksud. Melalui lembaga-lembaga internasional didirikanlah lembaga-lembaga untuk mempercepat pertumbuhan ekonomi di negara-negara berkembang seperti The World Bank, International Monetary Found (IMF) dan juga International Labour Organization (ILO). Lembaga-lembaga tersebut melakukan berbagai studi mengusulkan kebijakan dan turut campur tangan dalam pengambilan keputusan menyangkut berbagai bidang yang dianggap mempengaruhi pertumbuhan ekonomi suatu negara berkembang. ILO meluncurkan program untuk World Employment Programme (WEP) sebagai konsep sektor informal yang pertama kali diperkenalkan di dunia Internasional (ILO, 1972).

\subsection{Ciri-ciri Sektor Informal}

Adapun ciri-ciri kegiatan sektor informal dapat disimpulkan sebagai berikut: (i) manajemennya sederhana; (ii) tidak memerlukan izin usaha; (iii) modal rendah; (iv) padat karya; (v) tingkat produktivitas rendah; (vi) tingkat pendidikan formal biasanya rendah; (vii) penggunaan teknologi sederhana; (viii) sebagian besar pekerja adalah keluarga dan pemilikan usaha oleh keluarga; (ix) mudahnya keluar masuk usaha; dan (x) kurangnya dukungan dan pengakuan pemerintah.

\subsection{Munculnya Kegiatan Sektor Informal}

Ulasan tentang kegiatan-kegiatan sektor informal selama ini umumnya terfokus secara eksklusif pada konteks kontemporernya, yaitu membahas tentang tingkat penghasilan pengusaha, jumlah tenaga kerja, latar belakang sosial ekonomi para pekerja dan sebagainya. Ulasan-ulasan tersebut ternyata belum mampu memberikan gambaran yang utuh tentang fenomena informalitas. Oleh karena itu dalam hal ini perlu dijelaskan munculnya gejala sektor informal dalam konteks sejarah karena melalui sejarah ini dapat menyingkap akar-akar kegiatan sektor informal serta keterkaitannya dengan perkembangan-perkembangan makro dalam sistem sosial ekonomi yang lebih luas.

Sektor informal dengan segala persamaan dan perbedaan dengan sektor formal sering dipertukarkan dengan beragam istilah, diantaranya aktivitas informal (informal activity), kesempatan kerja yang diciptakan sendiri (self employment), ekonomi bawah tanah (underground economy), ekonomi pasar gelap (black market economy), ekonomi bayangan (shadow economy) maupun kerja sampingan (causal work) (Subarsono;2002;25).

Tabel 1. Persamaan dan Perbedaan Sektor Informal dengan Sektor Formal Perkotaan

\begin{tabular}{|c|c|c|}
\hline Aspek & Sektor Informal & Sektor Formal \\
\hline Skala Usaha & Kecil dan tak berbadan hukum & $\begin{array}{l}\text { Menengah hingga besar dan } \\
\text { berbadan hukum }\end{array}$ \\
\hline Kelayakan Usaha & Tidak ada/seadanya & Ada dan diprioritaskan \\
\hline Pembukuan Usaha & Tidak ada/sederhana & Ada sesuai standar \\
\hline Permodalan & Kecil & Menengah hingga besar \\
\hline Perencanaan Usaha & Ada sambil jalan & Ada dan terus menerus \\
\hline Sumber Modal & $\begin{array}{l}\text { - Milik sendiri/patungan } \\
\text { - Bermitra dengan bank plecit } \\
\text { (lembaga keuangan tidak resmi) }\end{array}$ & $\begin{array}{l}\text { - Milik sendiri/patungan } \\
\text { - Bermitra dengan bank umum } \\
\text { (lembaga keuangan resmi) }\end{array}$ \\
\hline Perputaran Modal & Cepat & Lambat \\
\hline Pengakuan Negara & Tidak ada/kecil & Diakui \\
\hline Perlindungan Hukum & Tidak ada/kecil & Dilindungi \\
\hline Bantuan Negara & Tidak ada/tidak sampai & Rutin \\
\hline Izin Usaha & Tidak resmi & Resmi dan negara \\
\hline Pemberi Izin & RT/RW/tetangga usaha & Negara \\
\hline Unit Usaha & Mudah berganti & Relatif Tetap \\
\hline Kegiatan Usaha & Kurang terorganisasi & Sangat terorganisasi \\
\hline Organisasi & Kekeluargaan & Birokrasi \\
\hline Teknologi & Sederhana dan padat karya & Modern dan padat modal \\
\hline Pendidikan Formal & Tidak begitu diperlukan & Sangat diperlukan \\
\hline
\end{tabular}




\begin{tabular}{|c|l|l|}
\hline \multicolumn{1}{|c|}{ Aspek } & \multicolumn{1}{|c|}{ Sektor Informal } & \multicolumn{1}{c|}{ Sektor Formal } \\
\hline Keterampilan & $\begin{array}{l}\text { Tidak berasal dari lembaga } \\
\text { formal/alamiah }\end{array}$ & Berasal dari lembaga formal \\
\hline Jam Kerja & Tidak tentu & Rutin, proesional \\
\hline Stok Barang & Sedikit hingga sedang & Sedang hingga besar \\
\hline Kualitas Barang & Rendah hingga menengah & Standar \\
\hline Omzet & Tidak tentu dan sulit diprediksi & $\begin{array}{l}\text { Tidak tentu akan tetapi dapat } \\
\text { diprediksi }\end{array}$ \\
\hline Khalayak Pasaran & Kelas bawah, menengah, atas & Kelas bawah, menengah, atas \\
\hline Jumlah Karyawan & Tidak tentu,biasanya 1-5 orang & Tidak tentu, lebih dari 5 orang \\
\hline Hubungan Kerja & $\begin{array}{l}\text { Kekeluargaan dan saling } \\
\text { percaya }\end{array}$ & $\begin{array}{l}\text { Berdasarkan kontrak yang } \\
\text { disepakati }\end{array}$ \\
\hline $\begin{array}{c}\text { Hubungan Majikan } \\
\text { Karyawan }\end{array}$ & Kekeluargaan, teman, tetangga & $\begin{array}{l}\text { Bebas memilih karyawan sesuai } \\
\text { kebutuhan }\end{array}$ \\
\hline Tempat Usaha & Mudah berpindah dan sempit & Permanen dan luas \\
\hline Kontribusi Negara & Relati kecil & Relatif besar \\
\hline Karakteristik Usaha & Mudah dimasuki & Sulit dimasuki \\
\hline
\end{tabular}

Sumber: Alisjahbana dalam Bagong dan Karnaji, Kemiskinan dan Kesenjangan Sosial,

Surabaya: Airlangga University Press, 2005, halaman 49

Senada dengan pembedaan Alisjahbana Jumlah sampel sendiri ditentukan menggunakan diatas, Hyla Mynt membedakan sektor modern dengan sektor tradisional kedalam beberapa karakteristik (Hyla Mint; 1985;30). Pertama, unit ekonomi dalam sektor modern sangat terspesialisasi dan terintegrasi penuh, sedangkan pada sektor tradisional memiliki derajat spesialisasi yang rendah. Kedua, sektor modern mencakup usaha-usaha besar yang padat modal dengan teknologi modern, sementara di sektor tradisional penggunaan alat-alat teknologi masih sederhana dan padat karya. Ketiga, usaha bisnis modern mempekerjakan tenaga kerja atas dasar regulasi dan membayar atas dasar produktivitas marjinal, sedangkan di sektor tradisional menyerap tenaga kerja dari lingkungan keluarga dan dibayar atas dasar produktivitas rataratanya. Keempat, unit ekonomi di sektor modern memiliki akses ke lembaga keuangan resmi, sedangkan sektor tradisional memiliki akses terbatas terhadap lembaga keuangan resmi, dan sering terjerat bunga mencekik dari lembaga keuangan tidak resmi.

\subsection{Identifikasi Persebaran Sektor Informal Kota Pematangsiantar}

Identifikasi persebaran sektor informal Kota Pematangsiantar, menggunakan data hasil survei plotting menggunakan GPS (Global Positioning System). Adapun persebaran pelaku usaha/kegiatan sektor informal diidentifikasi berdasarkan jumlah sampel yang diambil bersamaan dengan penyebaran kuisioner. metode pengambilan sampling.

Dari hal-hal di atas, maka ditentukan penarikan sampel untuk sektor informal di Kota Pematangsiantar menggunakan Purposive Sampling sebanyak 50 (lima puluh) responden yang dianggap sudah mewakili seluruh kegiatan/usaha sektor informal di Kota Pematangsiantar.

Berdasarkan hasil survei yang telah dilakukan, maka diketahui bahwa persebaran dari kegiatan/usaha sektor informal tersebar ke seluruh kecamatan Kota Pematangsiantar yaitu pada Kecamatan Siantar Barat terdapat sebanyak 11 unit sektor informal, Kecamatan Siantar Marihat terdapat sebanyak 3 unit sektor informal, Kecamatan Siantar Marimbun terdapat sebanyak 5 unit sektor informal, Kecamatan Siantar Martoba terdapat sebanyak 3 unit sektor informal, Kecamatan Siantar Selatan terdapat sebanyak 5 unit sektor informal, Kecamatan Siantar Sitalasari terdapat sebanyak 6 unit sektor informal, Kecamatan Siantar Timur terdapat sebanyak 10 unit sektor informal, dan pada Kecamatan Siantar Utara terdapat sebanyak 7 unit sektor informal. Dari data tersebut diketahui juga bahwa kegiatan/usaha sektor informal di Kota Pematangsiantar terpusat pada Kecamantan Siantar Barat dan Kecamatan Siantar Timur.

\subsection{Identifikasi Potensi dan Permasalahan Sektor Informal Kota Pematangsiantar}

Sektor informal, dengan segala keterbatasan yang dimiliki, tetapi juga 
tersimpan kekuatan luar biasa sebagai penyangga ribuan bahkan jutaan kelangsungan hidup warga. Dalam banyak penelitian, sektor ini mampu menjadi tempat berlindung hingga mencapai 70 persen tenaga kerja di negara sedang berkembang. Di kota-kota berkembang seperti Kota Pematangsiantar juga menunjukkan trend yang sama, mengalami kenaikan tiap tahunnya.

Bila kita meninjau sektor informal Kota Pematangsiantar berdasarkan kondisi karakteristiknya, maka terdapat potensi dan juga permasalahan yang dimiliki oleh sektor ini. Identifikasi potensi dan permasalahan sektor informal Kota Pematangsiantar sendiri menggunakan metode deksriptif kualitatif yang membandingkan keadaan sebenarnya antara yang terjadi pada sektor informal di Kota Pematangsiantar dengan teori/literatur terkait sektor informal.

\subsection{Potensi Sektor Informal Kota Pematangsiantar}

Berdasarkan hasil survei dan kuisioner terhadap 50 (lima puluh) orang responden, maka diketahui bahwa kegiatan/usaha sektor informal Kota Pematangsiantar memiliki potensi yang besar untuk menunjang kegiatan perekonomian di kota ini. Sektor ini mampu membuka lapangan pekerjaan baru untuk menjadi alternatif sumber mata pencaharian penduduk di Kota Pematangsiantar.

Selain penduduk asli Kota Pematangsiantar sendiri, hasil kuisioner yang dilakukan juga menunjukkan bahwa pelaku kegiatan/usaha pada sektor informal ini juga berasal dari luar wilayah Kota Pematangsiantar. Hal ini sendiri sesuai dengan penelitian yang dilakukan oleh Bappenas pada Tahun 2009 yang menyatakan bahwa munculnya sektor informal di kota tidak terlepas dari latar belakang sejarah perekonomian tradisional yaitu perekonomian pedesaan yang sebagian besar didasarkan pada struktur pertanian dengan pola bercocok tanam sederhana. Oleh karena rendahnya upah tenaga kerja di sektor pertanian dan semakin langkanya lahan-lahan pertanian di pedesaan, maka banyak tenaga kerja yang memilih alternatif lain untuk urbanisasi dan bekerja di sektor non pertanian. Dalam hubungan ini ternyata sebagian besar angkatan kerja terserap pada sektor informal.

Pada RPJP (Rencana Pembangunan Jangka Panjang) Daerah Kota Pematangsiantar Tahun 2005-2025 dan di dalam RTRW (Rencana Tata Ruang Wilayah) Kota Pematangsiantar Tahun 2012-2032 menyebutkan bahwa kota ini bertujuan untuk menjadi pusat tengah kegiatan perdagangan dan jasa di Provinsi Sumatera Utara. Terdapat juga beberapa kebijakan yang mendukung keberadaan serta pengembangan sektor informal. Dengan adanya kebijakan yang dibuat oleh Pemerintah Daerah Kota Pematangsiantar ini, maka potensi dari sektor informal di kota ini semakin besar terhadap roda pergerakkan perekonomian. Sektor ini akan ikut menyumbang pendapatan daerah yang dihasilkan dari pajak atau retribusi dengan catatan bahwa hal tersebut untuk mengembangkan dan mendukung keberadaan sektor ini sendiri.

\subsection{Identifikasi Faktor Internal dan Eksternal Sektor Informal Kota Pematangsiantar}

Teori tentang sektor informal pertama kali diperkenalkan Keith Harth, seorang antropolog Inggris dari Manchester University. Harth menggambarkan sektor informal sebagai angkatan kerja perkotaan (urban labour force), yang berada di luar pasaran tenaga kerja yang terorganisir dan teratur. Menyatakan bahwa sektor informal perkotaan di Indonesia disamping merupakan urban labour force yang berada di luar pasaran tenaga kerja yang terorganisir dan teratur, juga tidak mempunyai hubungan formal dengan pemerintah dan tidak tergantung pada bahan-bahan atau teknologi impor, serta jangkauan (radius) pemasarannya tidak terlalu luas.

Tabel 2. Faktor Internal dan Faktor Eksternal Sektor Informal

\begin{tabular}{|c|c|c|c|}
\hline \multicolumn{2}{|c|}{ Faktor Internal Sektor Informal } & \multicolumn{2}{|c|}{ Faktor Eksternal Sektor Informal } \\
\hline \multirow{5}{*}{ Kekuatan } & Motivasi & \multirow{5}{*}{ Peluang } & Lapangan kerja baru \\
\hline & Kreatifitas & & Pendapatan kota \\
\hline & Banyak macam/jenis usaha & & Tahan krisis ekonomi \\
\hline & Modal kecil & & Perkembangan kota \\
\hline & Pengalaman kerja & & Permintaan konsumen tinggi \\
\hline \multirow{2}{*}{ Kelemahan } & Tingkat pendidikan & \multirow{2}{*}{ Ancaman } & Penggusuran/relokasi \\
\hline & Tidak memiliki izin & & Perdagangan bebas \\
\hline
\end{tabular}




\begin{tabular}{|l|l|l|l|}
\hline \multicolumn{2}{|c|}{ Faktor Internal Sektor Informal } & \multicolumn{2}{|l|}{ Faktor Eksternal Sektor Informal } \\
\hline \multirow{2}{*nn}{} & Ketersediaan bahan baku & Persaingan sektor formal \\
& Sarana dan Prasarana & Biaya sewa \\
& Sumber Modal & Kebijakan pembangunan \\
\hline
\end{tabular}

Sumber : ILO, Tahun 1972:11

Pembahasan mengenai identifikasi faktor internal dan faktor eksternal terhadap pengembangan sektor informal di Kota Pematangsiantar diperlukan untuk mengetahui kekuatan dan kelemahan serta peluang maupun ancaman yang dimiliki oleh para pelaku kegiatan/usaha sektor informal. Berdasarkan Tabel Faktor Internal dan Faktor Eksternal yang dikemukakan oleh ILO/UNDP (International Labour Organization/United Nations Development Programme) pada Tahun 1972, maka faktor-faktor tersebut ditentukan dan dijadikan variabel terhadap pertanyaan yang ada di dalam kuisioner yang diambil secara acak dengan jumlah yang telah ditentukan pada pembahasan sebelumnya yaitu sebanyak 50 (lima puluh) koresponden.

\subsection{Faktor Internal Sektor Informal (Kekuatan dan Kelemahan)}

Seperti yang telah diuraikan sebelumnya, faktor internal sektor informal terdiri dari kekuatan dan kelemahan. Variabel-variabel dari faktor internal ini dijadikan pertanyaan di dalam kuisioner. Responden akan disuruh memilih mana dari variabel-variabel yang telah ditentukan yang menjadi kekuatan dan kelemahan yang dimiliki oleh kegiatan/usaha mereka. Berikut ini adalah faktor internal sektor informal Kota Pematangsiantar:

a. Kekuatan (Strengths)

1. Motivasi

2. Kreatifitas

3. Banyak macam/jenis usaha

4. Modal kecil

5. Pengalaman kerja

b. Kelemahan (Weaknesses)

1. Tingkat pendidikan
2. Tidak memiliki izin

3. Ketersedian bahan baku

4. Sarana dan prasarana

5. Sumber modal

Setelah menentukan setiap variabel dari faktor internal tersebut, tahapan selanjutnya adalah melakukan pembobotan dan skoring terhadap variabel-variabel tersebut. Pembobotan sendiri dilakukan berdasarkan jumlah responden yang memilih salah satu variabel yang telah ditetapkan sebelumnya. Perhitungan sendiri dilakukan dengan cara jumlah responden yang memilih salah satu variabel dibagi total jumlah responden yaitu 50 (lima puluh) koresponden. Pembobotan pada faktor internal tingkat kepentingannya didasarkan pada besarnya pengaruh faktor strategis terhadap posisi strategisnya (Freddy Rangkuti, 2001 : 22-24). Jumlah bobot pada masing-masing faktor internal harus berjumlah $=1$ (satu) :

\section{Skor Total Internal $\rightarrow$ Total Bobot Kekuatan + Total Bobot Kelemahan $=1$}

Sedangakan nilai bobot menurut Freddy Rangkuti (2001 : 22-24) dan Diklat Spama (2000 : 13-14) berdasarkan ketentuan sebagai berikut :

\section{"Skala 1,0 (sangat penting) sampai dengan 0,0 (tidak penting)"}

Besarnya rata-rata nilai bobot bergantung pada jumlah faktor-faktor strategisnya (5-10 faktor strategis) yang dipakai. Hal ini menunjukkan bahwa tingkat kepentingan relatif untuk masing-masing faktor. Untuk lebih jelasnya mengenai pembobotan faktor internal sektor informal Kota Pematangsiantar dapat dilihat pada

Tabel 3. Pembobotan Faktor Internal Sektor Informal Kota Pematangsiantar

\begin{tabular}{|c|l|c|c|}
\hline No. & \multicolumn{1}{|c|}{ Faktor Internal } & $\begin{array}{c}\text { Responden } \\
\text { (org) }\end{array}$ & Pembobotan \\
\hline A & Kekuatan (No.Pertanyaan: 20) & & \\
\hline 1 & Motivasi & 12 & 0,120 \\
\hline 2 & Kreatifitas & 16 & 0,160 \\
\hline 3 & Banyak macam/jenis usaha & 10 & 0,100 \\
\hline 4 & Modal kecil & 4 & 0,040 \\
\hline 5 & Pengalaman kerja & 8 & 0,080 \\
\hline
\end{tabular}




\begin{tabular}{|c|l|c|c|}
\hline \multicolumn{2}{|c|}{ Jumlah } & $\mathbf{5 0}$ & $\mathbf{0 , 5 0}$ \\
\hline B & Kelemahan (No.Pertanyaan: 21) & & \\
\hline 1 & Tingkat pendidikan & 6 & 0,060 \\
\hline 2 & Tidak memiliki izin & 5 & 0,050 \\
\hline 3 & Ketersediaan bahan baku & 13 & 0,130 \\
\hline 4 & Sarana dan prasarana & 17 & 0,170 \\
\hline 5 & Sumber modal & 9 & 0,090 \\
\hline \multicolumn{2}{|c|}{ Jumlah } & $\mathbf{5 0}$ & $\mathbf{0 , 5 0}$ \\
\hline \multicolumn{2}{|c|}{ Total } & $\mathbf{1 , 0 0}$ \\
\hline
\end{tabular}

Sumber : Hasil Analisis, Tahun 2017

Dan untuk melakukan skoring terhadap Nilai skoring ditentukan berdasarkan besarnya faktor internal sektor informal Kota pengaruh faktor strategis terhadap kondisi Pematangsiantar adalah berdasarkan jumlah dirinya (Freddy Rangkuti, $2001: 22-24$ ) dengan responden yang memilih salah satu variabel. kententuan sebagai berikut:

Tabel 4. Interval Kelas Skoring Faktor Internal

\begin{tabular}{|c|c|c|l|}
\hline Faktor Internal & Skor Kelas & Interval & \multicolumn{1}{|c|}{ Keterangan } \\
\hline \multirow{3}{*}{ Kekuatan (+) } & 1 & $1-4$ responden & Lemah \\
\cline { 2 - 4 } & 2 & $5-9$ responden & Rata-rata \\
\cline { 2 - 4 } & 3 & $10-14$ responden & Kuat \\
\cline { 2 - 4 } & 4 & $>15$ responden & Sangat kuat \\
\hline \multirow{3}{*}{ Kelemahan (-) } & 4 & $1-4$ responden & Lemah \\
\cline { 2 - 4 } & 3 & $5-9$ responden & Rata-rata \\
\cline { 2 - 4 } & 2 & $10-14$ responden & Kuat \\
\cline { 2 - 4 } & 1 & $>15$ responden & Sangat kuat \\
\hline
\end{tabular}

Sumber : Hasil Analisis, Tahun 2017

Variabel yang bersifat positif (variabel sejenis) nilainya adalah 1, sedangkan jika nilai kekuatan) diberi nilai dari 1 sampai dengan 4 kelemahan kecil/di bawah rata-rata pesaingdengan membandingkan dengan rata-rata pesaingnya nilainya 4. Untuk lebih jelasnya pesaing utama. Sedangkan variabel yang mengenai skoring faktor internal sektor bersifat negatif kebalikannya, jika kelemahan informal Kota Pematangsiantar dapat dilihat besar sekali (dibanding dengan rata-rata pesaing pada Tabel 5.

Tabel 5. Skoring Faktor Internal Sektor Informal Kota Pematangsiantar

\begin{tabular}{|c|l|c|c|}
\hline No. & \multicolumn{1}{|c|}{ Faktor Internal } & Responden (org) & Skoring \\
\hline A & Kekuatan (No.Pertanyaan: 20) & & \\
\hline 1 & Motivasi & 12 & 3 \\
\hline 2 & Kreatifitas & 16 & 4 \\
\hline 3 & Banyak macam/jenis usaha & 10 & 3 \\
\hline 4 & Modal kecil & 4 & 1 \\
\hline 5 & Pengalaman kerja & 8 & 2 \\
\hline & Jumlah & $\mathbf{5 0}$ & \\
\hline B & Kelemahan (No.Pertanyaan: 21$)$ & & 3 \\
\hline 1 & Tingkat pendidikan & 6 & 3 \\
\hline 2 & Tidak memiliki izin & 5 & 2 \\
\hline 3 & Ketersediaan bahan baku & 13 & 1 \\
\hline 4 & Sarana dan prasarana & 17 & 3 \\
\hline 5 & Sumber modal & 9 & \\
\hline & Jumlah & $\mathbf{5 0}$ & \\
\hline
\end{tabular}

Sumber : Hasil Analisis, Tahun 2017 
Setelah melakukan pembobotan dan skoring, hal yang dilakukan selanjutnya adalah melakukan matriks terhadap faktor internal sektor informal Kota Pematangsiantar. Di dalam matriks ini adalah merupakan perhitungan dari nilai bobot masing-masing

Tabel 6. Matriks Faktor Strategi Internal Sektor Informal Kota Pematangsiantar

\begin{tabular}{|c|l|c|c|c|}
\hline No. & \multicolumn{1}{|c|}{ Faktor Internal } & Bobot & Skor & $\begin{array}{c}\text { Sub } \\
\text { Total }\end{array}$ \\
\hline A & Kekuatan (No.Pertanyaan: 20) & & & \\
\hline 1 & Motivasi & 0,120 & 3 & 0,360 \\
\hline 2 & Kreatifitas & 0,160 & 4 & 0,640 \\
\hline 3 & Banyak macam/jenis usaha & 0,100 & 3 & 0,300 \\
\hline 4 & Modal kecil & 0,040 & 1 & 0,040 \\
\hline 5 & Pengalaman kerja & 0,080 & 2 & 0,160 \\
\hline \multicolumn{2}{|}{ Jumlah } & $\mathbf{0 , 5 0}$ & & $\mathbf{1 , 5 0}$ \\
\hline B & Kelemahan (No.Pertanyaan: 21) & & & \\
\hline 1 & Tingkat pendidikan & 0,060 & 3 & 0,180 \\
\hline 2 & Tidak memiliki izin & 0,050 & 3 & 0,150 \\
\hline 3 & Ketersediaan bahan baku & 0,130 & 2 & 0,260 \\
\hline 4 & Sarana dan prasarana & 0,170 & 1 & 0,170 \\
\hline 5 & Sumber modal & 0,090 & 3 & 0,270 \\
\hline \multicolumn{2}{|c|}{ Jumlah } & $\mathbf{0 , 5 0}$ & & $\mathbf{1 , 0 3}$ \\
\hline \multicolumn{2}{|c|}{ Total } & $\mathbf{1 , 0 0}$ & & $\mathbf{2 , 5 3}$ \\
\hline
\end{tabular}

Sumber : Hasil Analisis, Tahun 2017

Setelah melakukan analisis, dapat diketahui bahwa pada variabel kekuatan (strengths) yang memiliki sub total tertinggi adalah kreatifitas dengan nilai 0,640. Dan untuk variabel kelemahan (weaknesses) yang memiliki sub total tertinggi adalah sumber modal dengan nilai 0,270 .

\subsection{Faktor Eksternal Sektor Informal (Peluang dan Ancaman)}

Seperti yang telah diuraikan sebelumnya, faktor eksternal sektor informal terdiri dari peluang dan ancaman. Variabel dari faktor eksternal ini dijadikan pertanyaan di dalam kuisioner. Responden akan disuruh memilih mana dari variabel-variabel yang telah ditentukan yang menjadi kekuatan dan kelemahan yang dimiliki oleh kegiatan/usaha mereka. Berikut ini adalah faktor eksternal sektor informal Kota Pematangsiantar:

\section{A. Peluang (Opportunities)}
a) Lapangan kerja baru
b) Pendapatan Asli Daerah (PAD)
c) Tahan akan krisis ekonomi
d) Perkembangan kota

variabel dikalikan dengan nilai skor masingmasing variabel. Matriks Faktor Strategi Internal (IFAS: Internal Factors Analysis

Summary) Sektor Informal Kota Pematangsiantar. 
Skor Total Eksternal $\rightarrow$ Total Bobot

Peluang + Total Bobot Ancaman = 1

Sedangakan nilai bobot menurut Freddy Rangkuti (2001 : 22-24) dan Diklat Spama (2000 : 13-14) berdasarkan ketentuan sebagai berikut :

"Skala 1,0 (sangat penting) sampai dengan 0,0 (tidak penting)".
Besarnya rata-rata nilai bobot bergantung pada jumlah faktor-faktor strategisnya (5-10 faktor strategis) yang dipakai. Hal ini menunjukkan bahwa tingkat kepentingan relatif untuk masing-masing faktor. Untuk lebih jelasnya mengenai pembobotan faktor eksternal sektor informal Kota Pematangsiantar dapat dilihat

Tabel 7. Pembobotan Faktor Eksternal Sektor Informal Kota Pematangsiantar

\begin{tabular}{|c|l|c|c|}
\hline No. & \multicolumn{1}{|c|}{ Faktor Eksternal } & $\begin{array}{c}\text { Responden } \\
\text { (org) }\end{array}$ & Pembobotan \\
\hline A & Peluang (No.Pertanyaan: 22) & & \\
\hline 1 & Lapangan kerja baru & 17 & 0,170 \\
\hline 2 & Pendapatan Asli Daerah (PAD) & 10 & 0,100 \\
\hline 3 & Tahan akan krisis ekonomi & 3 & 0,030 \\
\hline 4 & Perkembangan kota & 7 & 0,070 \\
\hline 5 & Permintaan konsumen tinggi & 13 & 0,130 \\
\hline \multicolumn{2}{|c|}{ Jumlah } & $\mathbf{5 0}$ & $\mathbf{0 , 5 0}$ \\
\hline B & Ancaman (No.Pertanyaan: 23) & 16 & 0,160 \\
\hline 1 & Penggusuran & 3 & 0,030 \\
\hline 2 & Perdagangan bebas & 10 & 0,100 \\
\hline 3 & Persaingan dengan sektor formal & 13 & 0,130 \\
\hline 4 & Biaya sewa & 8 & 0,080 \\
\hline 5 & Kebijakan pembangunan & $\mathbf{5 0}$ & $\mathbf{0 , 5 0}$ \\
\hline \multicolumn{2}{|c|}{ Jumlah } & & $\mathbf{1 , 0 0}$ \\
\hline & \multicolumn{2}{|c|}{ Total }
\end{tabular}

Sumber : Hasil Analisis, Tahun 2017

Dan untuk melakukan skoring terhadap Nilai skoring ditentukan berdasarkan besarnya faktor eksternal sektor informal Kota pengaruh faktor strategis terhadap kondisi Pematangsiantar adalah berdasarkan jumlah dirinya (Freddy Rangkuti, 2001 : 22-24) dengan responden yang memilih salah satu variabel. kententuan sebagai berikut:

Tabel 8. Interval Kelas Skoring Faktor Eksternal

\begin{tabular}{|c|c|c|l|}
\hline $\begin{array}{c}\text { Faktor } \\
\text { Eksternal }\end{array}$ & $\begin{array}{c}\text { Skor } \\
\text { Kelas }\end{array}$ & \multicolumn{1}{|c|}{ Interval } & \multicolumn{1}{|c|}{ Keterangan } \\
\hline \multirow{4}{*}{$\begin{array}{c}\text { Peluang } \\
(+)\end{array}$} & 1 & $1-4$ responden & Lemah \\
\cline { 2 - 4 } & 2 & $5-9$ responden & Rata-rata \\
\cline { 2 - 4 } & 3 & $10-14$ responden & Kuat \\
\cline { 2 - 4 } & 4 & $>15$ responden & Sangat kuat \\
\cline { 2 - 4 } $\begin{array}{c}\text { Ancaman } \\
(-)\end{array}$ & 4 & $1-4$ responden & Lemah \\
\cline { 2 - 4 } & 2 & $10-9$ responden & Rata-rata \\
\cline { 2 - 4 } & 1 & $>15$ responden & Kuat \\
\hline
\end{tabular}

Sumber : Hasil Analisis, Tahun 2017

Variabel yang bersifat positif (variabel peluang) diberi nilai dari 1 sampai dengan 4 dengan membandingkan dengan rata-rata pesaing utama. Sedangkan variabel yang bersifat negatif kebalikannya, jika ancaman besar sekali (dibanding dengan rata-rata pesaing sejenis) nilainya adalah 1 , sedangkan jika nilai ancaman kecil/di bawah rata-rata pesaingpesaingnya nilainya 4 . Untuk lebih jelasnya mengenai skoring faktor eksternal sektor informal Kota Pematangsiantar dapat dilihat 
Tabel 9. Skoring Faktor Eksternal Sektor Informal Kota Pematangsiantar

\begin{tabular}{|c|l|c|c|}
\hline No. & \multicolumn{1}{|c|}{ Faktor Eksternal } & $\begin{array}{c}\text { Responden } \\
\text { (org) }\end{array}$ & Skoring \\
\hline A & Peluang (No.Pertanyaan: 22) & & \\
\hline 1 & Lapangan kerja baru & 17 & 4 \\
\hline 2 & Pendapatan Asli Daerah (PAD) & 10 & 3 \\
\hline 3 & Tahan akan krisis ekonomi & 3 & 1 \\
\hline 4 & Perkembangan kota & 7 & 2 \\
\hline 5 & Permintaan konsumen tinggi & 13 & 3 \\
\hline \multicolumn{2}{|}{ Jumlah } & $\mathbf{5 0}$ & \\
\hline B & Ancaman (No.Pertanyaan: 23) & & \\
\hline 1 & Penggusuran & 16 & 1 \\
\hline 2 & Perdagangan bebas & 3 & 4 \\
\hline 3 & Persaingan dengan sektor formal & 10 & 2 \\
\hline 4 & Biaya sewa & 13 & 2 \\
\hline 5 & Kebijakan pembangunan & 8 & 3 \\
\hline & Jumlah & $\mathbf{5 0}$ & \\
\hline
\end{tabular}

Sumber : Hasil Analisis, Tahun 2017

Setelah melakukan pembobotan dan skoring, hal yang dilakukan selanjutnya adalah melakukan matriks terhadap faktor eksternal sektor informal Kota Pematangsiantar. Di dalam matriks ini adalah merupakan variabel dikalikan dengan nilai skor masingmasing variabel. Matriks Faktor Strategi Eksternal (EFAS: External Factors Analysis Summary) Sektor Informal Kota perhitungan dari nilai bobot masing-masing Pematangsiantar.

Tabel 10. Matriks Faktor Strategi Eksternal Sektor Informal Kota Pematangsiantar

\begin{tabular}{|c|l|c|c|c|}
\hline No. & \multicolumn{1}{|c|}{ Faktor Eksternal } & Bobot & Skor & $\begin{array}{c}\text { Sub } \\
\text { Total }\end{array}$ \\
\hline A & Peluang (No.Pertanyaan: 22) & & & \\
\hline 1 & Lapangan kerja baru & 0,170 & 4 & 0,680 \\
\hline 2 & Pendapatan Asli Daerah (PAD) & 0,100 & 3 & 0,300 \\
\hline 3 & Tahan akan krisis ekonomi & 0,030 & 1 & 0,030 \\
\hline 4 & Perkembangan kota & 0,070 & 2 & 0,140 \\
\hline 5 & Permintaan konsumen tinggi & 0,130 & 3 & 0,390 \\
\hline & Jumlah & $\mathbf{0 , 5 0}$ & & $\mathbf{1 , 5 4}$ \\
\hline $\mathbf{B}$ & Ancaman (No.Pertanyaan: $\mathbf{2 3})$ & & & \\
\hline 1 & Penggusuran & 0,160 & 1 & 0,160 \\
\hline 2 & Perdagangan bebas & 0,030 & 4 & 0,120 \\
\hline 3 & Persaingan dengan sektor formal & 0,100 & 2 & 0,200 \\
\hline 4 & Biaya sewa & 0,130 & 2 & 0,260 \\
\hline 5 & Kebijakan pembangunan & 0,080 & 3 & 0,240 \\
\hline & Jumlah & $\mathbf{0 , 5 0}$ & & $\mathbf{0 , 9 8}$ \\
\hline & Total & $\mathbf{1 , 0 0}$ & & $\mathbf{2 , 5 2}$ \\
\hline
\end{tabular}

Sumber : Hasil Analisis, Tahun 2017

Setelah melakukan analisis, dapat ancaman (threats) sektor informal yang diketahui bahwa pada variabel peluang memiliki sub total tertinggi adalah biaya sewa (opportunities) sektor informal yang memiliki dengan nilai 0,260.

sub total tertinggi adalah lapangan kerja baru Setelah melakukan tahapan identifikasi dengan nilai 0,680. Dan untuk variabel faktor internal dan faktor eksternal sektor 
informal Kota Pematangsiantar, maka dapat disimpulkan bahwa:

\section{Faktor Internal (IFAS) Sektor}

\section{Informal Kota Pematangsiantar}

Diketahui bahwa sub total dari variabelvariabel pada kekuatan sektor informal Kota Pematangsiantar memiliki jumlah nilai sebesar 1,50 , dan untuk variabel-variabel pada kelemahan sektor informal Kota Pematangsiantar memiliki jumlah nilai sebesar 1,03. Hal ini menjelaskan bahwa variabel kekuatan sektor informal Kota Pematangsiantar masih lebih strategis bila dibandingkan dengan variabel kelemahan yang dimiliki oleh sektor ini.

\section{Faktor Eksternal (EFAS) Sektor Informal Kota Pematangsiantar}

Diketahui bahwa sub total dari variabelvariabel pada peluang sektor informal Kota Pematangsiantar memiliki jumlah nilai sebesar 1,54 , dan untuk variabel-variabel pada ancaman sektor informal Kota Pematangsiantar memiliki jumlah nilai sebesar 0,98 . Hal ini menjelaskan bahwa variabel peluang sektor informal Kota Pematangsiantar masih lebih strategis bila dibandingkan dengan variabel ancaman yang dimiliki oleh sektor ini.

\section{Analisis Strategi Pengembangan Sektor Informal Kota Pematangsiantar}

Setelah melakukan tahapan identifikasi faktor internal dan faktor eksternal kegiatan/usaha sektor informal Kota Pematangsiantar, maka langkah selanjutnya adalah melakukan analisis SWOT guna mendapatkan strategi pengembangan sektor informal Kota Pematangsiantar yang tepat sasaran. Matriks SWOT pada intinya adalah mengkombinasikan peluang, ancaman, kekuatan, dan kelemahan dalam sebuah matriks. Dengan demikian, matriks tersebut terdiri atas empat kuadran, dimana tiap-tiap kuadran memuat masing-masing strategi. Matriks SWOT merupakan pendekatan yang paling sederhana dan cenderung bersifat subyektif-kualitatif. Matriks ini menggambarkan secara jelas bagaimana peluang dan ancaman eksternal yang dihadapi organisasi dapat disesuaikan dengan kekuatan dan kelemahan yang dimilikinya.

Dari tahapan identifikasi faktor internal dan faktor eksternal sektor informal Kota Pematangsiantar yang didapatkan dari hasil pembobotan dan skoring sehingga membentuk matriks IFAS dan EFAS, maka hasilnya adalah:

\section{Nilai IFAS:}

- Kekuatan (strenghts) $\quad=1,50$

- Kelemahan (weaknesses) $\quad=1,03$

- Sub total pembobotan dan skoring $=\mathbf{2 , 5 3}$

Nilai EFAS:

- Peluang (opportunities) $\quad=1,54$

- Ancaman (threats) $\quad=0,98$

- Sub total pembobotan dan skoring $=\mathbf{2 , 5 2}$

Keseluruhan faktor internal dan eksternal yang telah diidentifikasi dalam matriks EFAS dan IFAS dikelompokkan dalam matriks SWOT yang kemudian secara kualitatif dikombinasikan untuk menghasilkan klasifikasi strategi yang meliputi empat set kemungkinan alternatif strategi, yaitu:

\section{a. Strategi S-O (Strengths - Opportunities)}

Kategori ini mengandung berbagai alternatif strategi yang bersifat memanfaatkan peluang dengan mendayagunakan kekuatan/kelebihan yang dimiliki. Strategi SO dipakai untuk menarik keuntungan dari peluang yang tersedia dalam faktor eksternal. Dengan kata lain, Pemerintah Daerah Kota Pematangsiantar harus mampu meraih semua peluang sektor informal berdasarkan kekuatankekuatan yang dimiliki. Setiap peluang harus ditangkap berdasarkan pertimbangan kekuatan yang dimiliki sektor informal, bukan sekedar karena adanya peluang tersebut. Strategi ini dipilih bila sub total penilaian matriks EFAS (Faktor Eksternal) lebih besar dari pada 2 dan sub total penilaian matriks IFAS (Faktor Internal) lebih besar daripada 2.

\section{b. Strategi W-O (Weaknesses - Opportunities)}

Kategori yang bersifat memanfaatkan peluang eksternal untuk mengatasi kelemahan. Strategi WO bertujuan untuk memperbaiki kelemahan sektor informal Kota Pematangsiantar dengan memanfaatkan peluang dari faktor yang terdapat di luar. Setiap peluang yang tidak dapat dipenuhi karena adanya kekurangan yang dimiliki, harus dicari jalan keluarnya dengan memanfaatkan kekuatankekuatan lainnya yang tersedia. Strategi ini dipilih bila sub total penilaian matriks EFAS (Faktor Eksternal) lebih besar dari pada 2 dan sub total penilaian matriks IFAS (Faktor Internal) lebih kecil atau sama dengan 2.

\section{c. Strategi S-T (Strengths - Threats)}

Kategori alternatif strategi yang memanfaatkan atau mendayagunakan kekuatan 
untuk mengatasi ancaman. Strategi ST digunakan untuk menghindari, paling tidak memperkecil dampak negatif dari ancaman terhadap sektor informal Kota Pematangsiantar atau tantangan yang akan datang dari luar. Jika ancaman tersebut tidak bisa diatasi dengan kekuatan internal maupun kekuatan eksternal yang ada, maka perlu dicari jalan keluarnya, agar ancaman tersebut tidak akan memberikan dampak negatif yang terlalu besar. Strategi ini dipilih bila sub total penilaian matriks EFAS (Faktor Eksternal) lebih kecil atau sama dengan 2 dan sub total penilaian matriks IFAS (Faktor Internal) lebih besar dari pada 2 .

d. Strategi W-T (Weaknesses - Threats)

Kategori alternatif strategi sebagai solusi dari penilaian atas kelemahan dan ancaman yang dihadapi, atau usaha menghindari ancaman untuk mengatasi kelemahan. Strategi WT adalah taktik mempertahankan kondisi yang diusahakan dengan memperkecil kelemahan sektor informal Kota Pematangsiantar dan menghindari ancaman. Dengan kata lain, jika sekiranya ancaman yang akan datang lebih kuat dari upaya pengembangan, maka hal yang perlu dilakukan, adalah dengan menghentikan sementara usaha ekspansi pengembangan, dengan menunggu ancaman eksternal yang datang menjadi hilang atau reda. Strategi ini dipilih bila sub total penilaian matriks EFAS (Faktor Eksternal) lebih kecil atau sama dengan 2 dan sub total penilaian matriks IFAS (Faktor Internal) lebih kecil atau sama dengan 2.

Dari penjelasan sebelumnya, maka berikut ini adalah Matriks Analisis SWOT terkait strategi pengembangan sektor informal di Kota Pematangsiantar. Untuk lebih jelasnya dapat dilihat.

Tabel 10. Matriks Analisis SWOT Sektor Informal Kota Pematangsiantar

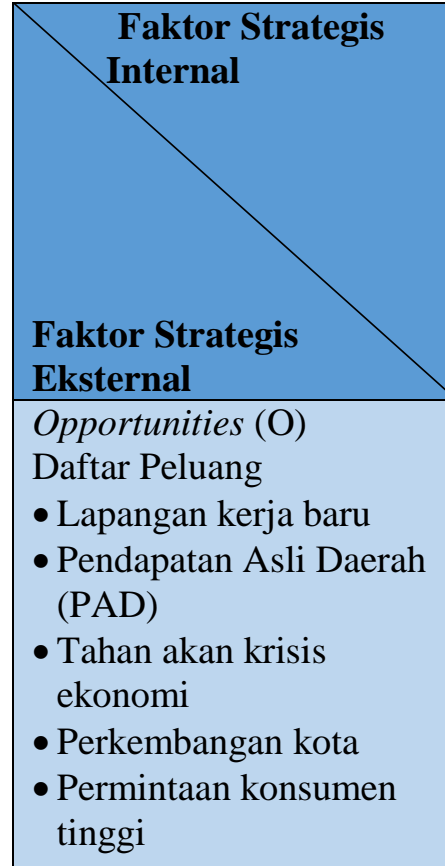

Strategi S-O

1. Pemerintah Daerah Kota

Pematangsiantar harus membuat kebijakan berupa Peraturan Daerah (Perda) yang mengatur terkait pelaksanaan dan pengembangan sektor informal.

2. Pemerintah Daerah Kota Pematangsiantar harus melakukan pendataan agar kegiatan/usaha sektor informal dapat terkoordinir secara baik.

3. Pemerintah Daerah Kota Pematangsiantar harus melakukan penyuluhan kepada pada pelaku kegiatan/usaha sektor informal terkait informasi peluang pasar.

4. Meningkatkan produktifitas sektor informal, dari yang awalnya kurang potensial menjadi usaha yang ekonomis dan padat karya.

5. Pemerintah Daerah Kota

\section{Weaknesses (W)}

Daftar Kelemahan

- Tingkat pendidikan

- Tidak memiliki izin

- Ketersediaan bahan baku

- Sarana dan prasarana

- Sumber modal

\section{Strategi W-O}

1. Memberikan pelatihan keterampilan (soft skill) kepada pelaku usaha sektor informal: pelatihan kewirausahaan, pelatihan teknis produksi maupun pelatihan teknis pembukuan.

2. Mendirikan paguyuban (kelembagaan) dalam bentuk koperasi atau yang lainnya, dan diatur di manajemen sendiri oleh para pelaku kegiatan/usaha sektor informal Kota

Pematangsiantar.

3. Menjadikan sumber daya (bahan baku) lokal sebagai basis utama agar lebih efisien,

4. Pemerintah Daerah Kota Pematangsiantar melakukan pendekatan terhadap para pelaku kegiatan/usaha sektor informal yang melakukan 


\begin{tabular}{|c|c|c|}
\hline $\begin{array}{l}\text { Faktor Strategis } \\
\text { Internal } \\
\text { Faktor Strategis } \\
\text { Eksternal }\end{array}$ & $\begin{array}{l}\text { Strenghts }(\mathrm{S}) \\
\text { Daftar Kekuatan } \\
\text { - Motivasi } \\
\text { - Kreatifitas } \\
\text { - Banyak macam/jenis usaha } \\
\text { - Modal kecil } \\
\text { - Pengalaman kerja }\end{array}$ & $\begin{array}{l}\text { Weaknesses }(\mathrm{W}) \\
\text { Daftar Kelemahan } \\
\text { - Tingkat pendidikan } \\
\text { - Tidak memiliki izin } \\
\text { - Ketersediaan bahan baku } \\
\text { - Sarana dan prasarana } \\
\text { - Sumber modal }\end{array}$ \\
\hline & $\begin{array}{l}\text { Pematangsiantar membantu } \\
\text { melakukan promosi terhadap } \\
\text { kegiatan/usaha sektor informal. }\end{array}$ & $\begin{array}{l}\text { usaha di tempat/lokasi yang } \\
\text { tidak seharusnya, untuk mau } \\
\text { direlokasi dan direvitalisasi. } \\
\text { 5. Menghadirkan lembaga } \\
\text { penjamin kredit dari } \\
\text { pemerintah bisa dalam bentuk } \\
\text { uang tunai maupun modal } \\
\text { peralatan. }\end{array}$ \\
\hline $\begin{array}{l}\text { Threats }(\mathrm{T}) \\
\text { Daftar Ancaman } \\
\text { - Penggusuran } \\
\text { - Perdagangan bebas } \\
\text { - Persaingan dengan } \\
\text { sektor formal } \\
\text { - Biaya sewa } \\
\text { - Kebijakan pembangunan }\end{array}$ & $\begin{array}{l}\text { Strategi S-T } \\
\text { 1. Pemerintah Daerah Kota } \\
\text { Pematangsiantar melakukan } \\
\text { penataan ruang kota untuk } \\
\text { menyediakan lahan } \\
\text { kegiatan/usaha sektor informal. } \\
\text { 2. Pemerintah Daerah Kota } \\
\text { Pematangsiantar harus } \\
\text { menumbuhkan pusat-pusat } \\
\text { pertumbuhan kota, sehingga } \\
\text { tidak tersentral pada satu titik } \\
\text { yang mengakibatkan } \\
\text { melonjaknya pertumbuhan } \\
\text { jumlah kegiatan/usaha sektor } \\
\text { informal ini. } \\
\text { 3. Pemerintah Daerah Kota } \\
\text { Pematangsiantar harus } \\
\text { mempermudah izin membuka } \\
\text { dan membangun usaha baru, } \\
\text { baik untuk usaha yang bergerak } \\
\text { di sektor formal maupun yang } \\
\text { bergerak di sektor informal, hal } \\
\text { ini untuk membuka dan } \\
\text { menstabilkan lapangan usaha } \\
\text { baru bagi tenaga kerja yang } \\
\text { membutuhkan. } \\
\text { 4. Pemerintah Daerah Kota } \\
\text { Pematangsiantar harus bisa } \\
\text { bekerjasama dan bersinergi } \\
\text { dengan kabupaten atau kota } \\
\text { disekitar Kota Pematangsiantar } \\
\text { sendiri. Hal ini diperlukan agar } \\
\text { tidak terjadi pusat pertumbuhan } \\
\text { ekonomi yang tidak seimbang } \\
\text { yang bisa menyebabkan tingkat } \\
\text { urbanisasi meningkat. } \\
\text { 5. Dengan berkembangnya sektor }\end{array}$ & $\begin{array}{l}\text { Strategi W-T } \\
\text { 1. Menyelenggarakan } \\
\text { pendidikan formal maupun } \\
\text { non formal yang berbasis } \\
\text { kepada enterpreneurship } \\
\text { (kewirausahaan), sehingga } \\
\text { akan muncul manusia- } \\
\text { manusia yang berjiwa usaha } \\
\text { mandiri yang tidak } \\
\text { membutuhkan lapangan } \\
\text { pekerjaan melainkan } \\
\text { menciptakan lapangan kerja. } \\
\text { 2. Pembentukan infrastruktur } \\
\text { pendamping yang dapat } \\
\text { membantu pelaku sektor } \\
\text { informal dalam menghadapi } \\
\text { lembaga pembiayaan, } \\
\text { mengadopsi teknologi, dan } \\
\text { mengakses pasar luas. Pusat } \\
\text { inkubasi bisnis dapat dimulai } \\
\text { dari masyarakat, tapi harus } \\
\text { didukung penuh Pemerintah } \\
\text { Daerah Kota Pematangsiantar. } \\
\text { 3. Kebijakan pengembangan } \\
\text { sektor informal Kota } \\
\text { Pematangsiantar lebih } \\
\text { diarahkan pada pemberdayaan } \\
\text { ekonomi rakyat. } \\
\text { 4. Mobilisasi sumber daya, baik } \\
\text { manajemen, keahlian, maupun } \\
\text { keuangan. Kelembagaan } \\
\text { pemerintah untuk mengatasi } \\
\text { masalah sektor informal Kota } \\
\text { Pematangsiantar diperkuat } \\
\text { dengan membuat kebijakan } \\
\text { dan program, yang mampu } \\
\text { memobilisasi berbagai sumber }\end{array}$ \\
\hline
\end{tabular}




\begin{tabular}{|c|c|c|}
\hline $\begin{array}{l}\text { Faktor Strategis } \\
\text { Internal } \\
\text { Faktor Strategis } \\
\text { Eksternal }\end{array}$ & $\begin{array}{l}\text { Strenghts }(\mathrm{S}) \\
\text { Daftar Kekuatan } \\
\text { - Motivasi } \\
\text { - Kreatifitas } \\
\text { - Banyak macam/jenis usaha } \\
\text { - Modal kecil } \\
\text { - Pengalaman kerja }\end{array}$ & $\begin{array}{l}\text { Weaknesses }(\mathrm{W}) \\
\text { Daftar Kelemahan } \\
\text { - Tingkat pendidikan } \\
\text { - Tidak memiliki izin } \\
\text { - Ketersediaan bahan baku } \\
\text { - Sarana dan prasarana } \\
\text { - Sumber modal }\end{array}$ \\
\hline & $\begin{array}{l}\text { informal, maka Pemerintah } \\
\text { Daerah Kota Pematangsiantar } \\
\text { dapat menerapkan insentif dan } \\
\text { disentif terhadap para pelaku } \\
\text { kegiatan/usaha sektor informal } \\
\text { terkait biaya sewa lahan } \\
\text { berjualan mereka. }\end{array}$ & $\begin{array}{l}\text { daya tersebut. } \\
\text { 5. Mendirikan komunitas yang } \\
\text { di dalamnya terdiri dari } \\
\text { kerjasama sektor informal, } \\
\text { pihak swasta, LSM, maupun } \\
\text { Pemerintah Daerah Kota } \\
\text { Pematangsiantar itu sendiri. }\end{array}$ \\
\hline
\end{tabular}

Sumber : Hasil Analisis, Tahun 2017

Dari tahapan analisis yang menghasilkan matriks SWOT Pengembangan Sektor Informal Kota Pematangsiantar, maka dianggap bahwa nilai yang paling strategis (Stategi Prioritas) berdasarkan Nilai IFAS $=2,53$ dan Nilai EFAS $=2,52$ adalah Strategi S-O (StrenghtsOpportunities) yang meggunakan kekuatan yang dimiliki oleh sektor informal Kota Pematangsiantar dipadu dengan peluangpeluang yang ada. Diketahui juga bahwa nilai total dari kekuatan (strenghts) $=1,50$ adalah yang paling besar di dalam faktor internal dan nilai total dari peluang (opportunities) $=1,54$ adalah yang paling besar di dalam faktor eksternal.

Adapun strategi prioritas yang harus diutamakan implementasinya terkait Pengembangan oleh Sektor Informal Kota Pematangsiantar adalah antara lain:

1. Pemerintah Daerah Kota Pematangsiantar menetapkan kebijakan berupa Peraturan Daerah (Perda) yang mengatur tentang pelaksanaan dan pengembangan sektor informal.

2. Pemerintah Daerah Kota Pematangsiantar harus melakukan penyuluhan dan pendataan kepada pada pelaku kegiatan/usaha sektor informal terkait informasi peluang pasar.

3. Meningkatkan produktifitas sektor informal, dari yang awalnya kurang potensial menjadi usaha yang ekonomis dan padat karya.

4. Pemerintah Daerah Kota Pematangsiantar membantu melakukan promosi terhadap kegiatan/usaha sektor informal.

\subsection{Analisis Arahan Pengembangan dan Konsep Penataan Sektor Informal Kota Pematangsiantar}

Pada identifikasi potensi dan permasalahan sektor informal Kota Pematangsiantar, diketahui bahwa potensi yang dimiliki adalah pertama sektor ini dapat menjadi alternatif pilihan penduduk Kota Pematangsiantar sebagai mata pencaharian, yang artinya sektor ini dapat menciptakan lapangan kerja baru. Selanjutnya, hal ini diperkuat oleh kebijakan-kebijakan Pemerintah Daerah Kota Pematangsiantar yang mendukung keberadaan dan pengembangan sektor ini. Dengan adanya potensi-potensi yang telah diuraikan sebelumnya, maka potensi selanjutnya adalah sektor ini dapat menjadi pemasukan bagi Kota Pematangsiantar berupa pendapatan asli daerah (PAD). Dan untuk permasalahan yang dimiliki oleh sektor informal Kota Pematangsiantar adalah yang pertama rendahnya kualitas tenaga kerja, maksud dari hal ini adalah bahwa keterampilan yang dimiliki oleh para pelaku kegiatan/usaha sektor informal Kota Pematangsiantar masih sangat rendah.

Berdasarkan beberapa sampel best practice keberhasilan pengembangan dan penataan sektor informal di daerah lainnya, maka dapat dirumuskan beberapa strategi yang dapat diberikan terkait arahan pengembangan dan penataan sektor informal Kota Pematangsiantar dengan kombinasi strategi pada Analisis SWOT sebelumnya yang juga telah dilakukan. Adapun rumusan strategi yang dihasilkan antara lain:

1. Rendahnya kualitas tenaga kerja, kebijakan yang dapat dilakukan adalah memberikan 
pelatihan keterampilan (soft skill) kepada pelaku usaha sektor informal: pelatihan kewirausahaan, pelatihan teknis produksi maupun pelatihan teknis pembukuan.

2. Tidak memiliki izin usaha, kebijakan yang dapat dilakukan adalah melakukan pendataan terhadap para pelaku kegiatan/usaha sektor informal, agar dapat dimonitoring, dievaluasi dan dibantu dalam usaha, pendirian kelembagaan berupa paguyuban ataupun koperasi yang mampu menjadi penyangga dan rumah bagi bertumbuhnya kreativitas di sektor informal.

3. Menjadikan citra kota dan dampak lingkungan yang buruk, kebijakan yang dapat dilakukan adalah melalui pendekatan terhadap para pelaku kegiatan/usaha sektor informal yang melakukan usaha di tempat/lokasi yang tidak seharusnya, agar mau direlokasi dan direvitalisasi.

4. Sumber modal, kebijakan yang dapat dilakukan adalah menghadirkan lembaga penjamin kredit dari pemerintah baik dalam bentuk uang tunai maupun modal peralatan.

5. Belum ada peraturan yang jelas dan mengikat, kebijakan yang dapat dilakukan adalah dengan membuat dan menetapkan sebuah Peraturan Daerah (Perda) yang berisi tentang pengaturan keberadaan sektor informal dan juga pengembangan sektor tersebut di Kota Pematangsiantar.

Sebagai acuan yang dapat digunakan oleh Pemerintah Daerah Kota Pematangsiantar di dalam mengimplementasikan Strategi Pengembangan Sektor Informal di Kota Pematangsiantar, maka dalam kajian ini akan merekomendasikan Arahan Pengembangan dan Konsep Penataan Sektor Informal Kota Pematangsiantar berdasarkan analisis strategi pengembangan sebelumnya berupa indikasi program yang di dalam tiap program-program tersebut akan dijabarkan tahapan kegiatannya.

\section{Kesimpulan}

Berdasarkan hasil identifikasi dan analisa Kajian Pengembangan dan Sektor Informal Kota Pematangsiantar, maka beberapa kesimpulan yang dapat ditarik sebagai berikut ini:

1) Faktor Internal Pengembangan Sektor Informal Kota Pematangsiantar terdiri dari beberapa faktor kekuatan dan kelemahan. Variabel dari kekuatan sektor informal Kota
Pematangsiantar adalah: motivasi, kreatifitas, banyak macam/jenis usaha, modal kecil, serta pengalaman kerja. Adapun variabel kelemahan sektor informal Kota Pematangsiantar adalah: tingkat pendidikan, tidak memiliki izin, ketersediaan bahan baku, sarana dan prasarana, serta sumber modal. Faktor Internal yang paling berpengaruh terhadap sektor informal di Kota Pematangsiantar adalah faktor Kreatifitas dan Sumber Modal.

2) Faktor Eksternal Pengembangan Sektor Informal Kota Pematangsiantar terdiri dari beberapa faktor peluang dan ancaman. Variabel dari peluang sektor informal Kota Pematangsiantar adalah: lapangan kerja baru, pendapatan asli daerah (PAD), tahan akan krisis ekonomi, perkembangan kota, serta permintaan konsumen tinggi. Dan untuk variabel ancaman sektor informal Kota Pematangsiantar adalah: penggusuran, perdagangan bebas, persaingan dengan sektor formal, biaya sewa, dan juga kebijakan pembangunan. Faktor Eksternal yang paling berpengaruh terhadap sektor informal di Kota Pematangsiantar adalah faktor Lapangan Kerja Bbru dan biaya sewa.

3) Arahan Pengembangan Sektor Informal terdiri dari beberapa strategi antara lain Strategi S-O, Strategi W-O, Strategi S-T, dan juga Strategi W-T.

4) Berdasarkan rumusan hasil identifikasi faktor internal dan eksternal sektor informal Kota Pematangsiantar dan juga analisis strategi pengembangan sektor informal Kota Pematangsiantar, maka ditentukan bahwa Strategi S-O menjadi strategi prioritas yang harus diutamakan pengimplementasinnya oleh Pemerintah Daerah Kota Pematangsiantar.

\section{DAFTAR PUSTAKA}

Breman,Jan.2000. The informal sector in research: theory and practice. Rotterdam:The Comparative Asian Studies Programme (CASP), University of Rotterdam.

Effendi, 1996. Sumber Daya Manusia, Peluang Kerja dan Kemiskinan, cetakan ke-2, Tiara Wacana Yogya. Yogyakarta.

Effendi, Tadjuddin Noer.1997. Pertumbuhan Ekonomi, Sektor Informal dan Kemiskinan di Kota, dalam Kumpulan Tulisan DR. Tadjuddin Noer Effendi, Yogyakarta: Pusat 
Penelitian Kependudukan Universitas Gadjah Mada

Evers, Hans Dieter, 1992. Informal Sector Trade in Central Java, Productive Employment, Labour Absorption Capacity and Policy Implications. Yogyakarta : PPK UGM. Evers, Hans Dieter and Tadjuddin Noer Effendi, 1992. Trade and Informal Sector Policy in Central Java. Population Studies Center, Gadjah Mada University, Yogyakarta

ILO.1972. "Development of the Rural Informal Sectors : Policies and Strategies (A Discussion Paper)". Makalah dalam Asian Sub-regional seminar on Employment Policies for the rural Informal sector in East and Southeast Asia, 24-28 May, Yogyakarta.

Luthfi, Asrizal. 2008. Kemiskinan Kota dan Sektor Informal, Surabaya.

Manning, Chris, 1984. Struktur Pekerja Sektor Informal dan Kemiskinan Di Kota, Pusat
Penelitian Kependudukan UGM, Yogyakarta. Manning, Chris dan Tadjuddin Noer Effendi (2001). Urbanisasi, Pengangguran dan Sektor Informal di Kota. Yayasan Obor Indonesia, Jakarta.

Mustafa, Ali, 2008. Model Transformasi Sektor Informal : Sejarah, Teori dan Praksis Pedagang Kaki Lima. PT. Inspire Indonesia, Malang

Nasution, M.Zein. 1988. "Sektor Informal di Perkotaan:Rumusan Permasalahan sebagai Prahipotesis Pembinaan." Dalam Kumpulan Makalah Seminar Mobilitas Penduduk dan Sektor Informal. Novena, 2003. Marginalisasi Sektor Informal, www.pastionline.com, (1 Juni 2004)

Ramli Rusli, 2000. Penciptaan Kesempatan Kerja Sektor Informal Pedagang Kaki Lima di DKI Jakarta, Unpad, Bandung 